\title{
Development and Survival of Nymphs of Podisus nigrispinus (Heteroptera: Pentatomidae) Fed with Caterpillars of Chlosyne lacinia saundersii (Lepidoptera: Nymphalidae)
}

\author{
Carlos Alberto Domingues da Silva ${ }^{1,2}$, Teresinha Vinha Zanuncio ${ }^{1}$, Bruno Gomes Cunha ${ }^{1}$, \\ Ancidériton Antonio de Castro ${ }^{1}$, Glauco da Cruz Canevari ${ }^{1}$, José Eduardo Serrão ${ }^{3}$ and \\ José Cola Zanuncio ${ }^{1 *}$ \\ ${ }^{I}$ Departamento de Biologia Animal; Universidade Federal de Viçosa; 36571-000; Viçosa - MG - Brasil. ${ }^{2}$ Empresa \\ Brasileira de Pesquisa Agropecuária; Centro Nacional de Pesquisa de Algodão; C.P.: 174; 58107-720; Campina \\ Grande - PB - Brasil. ${ }^{3}$ Departamento de Biologia Geral; Universidade Federal de Viçosa; 36571-000; Viçosa - MG \\ - Brasil
}

\begin{abstract}
The development and survival of Podisus nigrispinus (Dallas) (Heteroptera: Pentatomidae) nymphs fed on larvae of Chlosyne lacinia saundersii Doubleday \& Hewitson (Lepidoptera: Nymphalidae) was studied at $25 \pm 1{ }^{\circ} \mathrm{C}, 68 \pm 10 \%$ relative humidity and $12 \mathrm{~h}$ photo phase. $P$. nigrispinus developed until the adult stage when fed on $C$. lacinia saundersii caterpillars. However, the survival rate of $P$. nigrispinus during early instars allowed this predator to complement its diet with other preys and to maintain its populations in areas with the sunflower culture.
\end{abstract}

Key words: Hemiptera, Lepidoptera, Helianthus annuиs, predator

\section{INTRODUCTION}

The sunflower (Helianthus annuus L.) is cultivated in many regions of the world in about 18 million hectares (Camargo and Amabile, 2001). The increasing area with this culture in Brazil can be explained by the fact that it represents an alternative to corn and presents 20 to $25 \%$ lower production costs. On the other hand, the large area cultivated may favor the increase and diversity of insect pest populations. Chlosyne lacinia saundersii Doubleday and Hewitson, 1849 (Lepidoptera: Nymphalidae) is considered the most important pest of sunflower (Vendramin and Boiça Jr., 1994) because it causes intense defoliation on this plant (Nakano et al., 1981) what can make unfeasible the production of this culture (Camargo and Amabile, 2001).

The biological control of $C$. lacinia saundersii with predatory Pentatomidae can represent an economic and ecological viable alternative. This is reinforced by the fact that these natural enemies are found in agricultural and forest areas as important agents of biological control (De Clercq and Degheele, 1992; Molina-Rugama et al., 1997; Zanuncio et al., 2000). These predators can feed

* Author for correspondence: zanuncio@ufv.br 
on many pests mainly Lepidoptera and Coleoptera orders and alternative prey (Medeiros et al., 2003; Torres et al., 2002) but also on plants (Zanuncio et al., 2000; Zanuncio et al., 2006) with alternative prey (Zanuncio et al., 2001). Podisus sagitta (Heteroptera: Pentatomidae) was reported preying caterpillar of $C$. lacinia in plantations of sunflower in Venezuela (Arnal and Ramos, 1990) while the predator Alcaeorrhynchus grandis (Dallas) (Heteroptera: Pentatomidae) was found feeding on this prey in the State of Paraná, Brazil (Malaguido and Panizzi, 1998).

Considering the importance of $C$. lacinia saundersii for the sunflower culture and the reduced number of information on predators of this pest, the objective of this research was to study the development and the survival of nymphs of $P$. nigrispinus fed on caterpillars of $C$. lacinia saundersii.

\section{MATERIAL AND METHODS}

This work was carried out at the Laboratory of Biological Control of Insects/BIOAGRO of the Federal University of Viçosa (UFV) in Viçosa, of Minas Gerais State, Brazil at $25 \pm 1^{\circ} \mathrm{C}, 68 \pm 10 \%$ relative humidity and 12 hours photo phase (Lemos et al., 2006).

Caterpillars of $C$. lacinia saundersii were collected in a sunflower plantation in the Federal University of Viçosa and the eggs of the predator $P$. nigrispinus were obtained from a colony of the
Laboratory of the Biological Control of Insects at the UFV.

Two hundred eggs of $P$. nigrispinus were collected and transferred to a Petri dish $(12.0 \times 1.2 \mathrm{~cm})$ with a cotton moist ball fixed to the internal part of its covers (Ramalho et al., 2008). A total of 120 first instars nymphs of this predator were transferred to 12 Petri dishes with 10 nymphs inside each one. Second instars nymphs were fed on first or second instar caterpillars of $C$. lacinia saundersii which were changed every 48 hours.

The duration and survival of each instar, the weight of adults and the sex ratio of $P$. nigrispinus were recorded. This predator was sexed based on its external genitalia (Grazia, 1986). Differences on the duration of each instar of this predator that originated males or females were compared by the test "t."

\section{RESULTS AND DISCUSSION}

The survival of the nymph stage of $P$. nigrispinus fed on C. lacinia saundersii varied from 23.3 to $90.0 \%$ with lower value in the fifth (Table 1). No significant interactions were found between instar $\mathrm{x} \operatorname{sex}(F=1.58 ;$ d.f. $=4 ; P>0.1814)$. The duration of the immature stages of $P$. nigrispinus was affected by instar $(F=44.97 ;$ d.f $=4 ; P<0.0001)$ and predator sex $(F=3.88 ;$ d.f $=1 ; P<0.05)$, especially in the fifth one (Table 1).

Table 1 - Survival and duration (mean \pm standard deviation) during each instar and of the nymph period of Podisus nigrispinus (Heteroptera: Pentatomidae) fed with caterpillars of Chlosyne lacinia saundersii (Lepidoptera: Nymphalidae) at $25 \pm 1^{\circ} \mathrm{C}, 68 \pm 10 \%$ relative humidity and 12 hours photo phase.

\begin{tabular}{|c|c|c|c|c|c|c|}
\hline \multirow{2}{*}{ Instar } & \multirow{2}{*}{$\begin{array}{l}\text { Number of } \\
\text { Individuals }\end{array}$} & \multirow{2}{*}{$\begin{array}{c}\text { Survival } \\
(\%)\end{array}$} & \multicolumn{4}{|c|}{ Duration (days) \pm EP } \\
\hline & & & Female & ${ }^{1} \mathbf{n}$ & Male & ${ }^{1} \mathbf{n}$ \\
\hline First & 120 & 90.0 & $4.50 \pm 0.51$ & 78 & $4.54 \pm 0.14^{\mathrm{n} . \mathrm{s}}$ & 42 \\
\hline Second & 100 & 75.0 & $3.89 \pm 0.28$ & 65 & $3.92 \pm 0.37^{\text {n.s. }}$ & 35 \\
\hline Third & 88 & 66.0 & $6.00 \pm 0.64$ & 60 & $4.62 \pm 0.43^{\text {n.s. }}$ & 28 \\
\hline Fourth & 79 & 59.3 & $6.17 \pm 0.32$ & 56 & $6.08 \pm 0.31^{\text {n.s. }}$ & 23 \\
\hline Fifth & 31 & 23.3 & $8.67 \pm 0.28$ & 18 & $7.85 \pm 0.15^{*}$ & 13 \\
\hline Nymph stage & 31 & 25.8 & $29.22 \pm 0.83$ & 18 & $27.00 \pm 0.54^{*}$ & 13 \\
\hline
\end{tabular}

n.s. Non-significant at $5 \%$ probability by the test "t". "Significant at $5 \%$ probability by the test "t."

${ }^{1} \mathrm{n}$ : number of individuals that reached the adult stage 
The duration of first instar of $P$. nigrispinus with water was similar to that of this predator with this diet (Lemos et al., 2003; Zanuncio et al., 1990; Zamperline et al., 1992). This could be explained by the fact that nymphs of predatory Pentatomidae did not prey during the first instar (MolinaRugama et al., 1998). Therefore, the duration and survival of this instar of $P$. nigrispinus was not influenced by the prey.

The duration of the second instar of $P$. nigrispinus with caterpillars of $C$. lacinia saundersii was longer than that of this predator fed on third or fifth instar caterpillars of $A$. argillacea (Lemos et al., 2003), larvae of B. mori (Zanuncio et al., 1990) or larvae of T. molitor (Zamperline et al., 1992; Lemos et al., 2003). However, the duration of the nymph stage of $P$. nigrispinus presented higher values for the nymph stage than when fed on third instar larvae of Musca domestica L. (Diptera: Muscidae) (Zanuncio et al., 1990; Lemos et al. 2003). The duration of the other instars of this predator was shorter with caterpillars of $C$. lacinia saundersii than with those of third or fifth instar $A$. argillacea (Lemos et al., 2003), third instar larvae M. domestica (Zanuncio et al., 1990; Lemos et al. 2003), caterpillars of B. mori (Zanuncio et al., 1990) or larvae of T. molitor (Zamperline et al., 1992; Lemos et al., 2003). Caterpillars exhibit a wide variety of behavior, morphology and physiology differences what can difficult to separate those that have defense function against many vertebrate, invertebrate, and microbial enemies (Gentry and Dyer, 2002). Lepidoptera larvae use morphological traits, such as scoli, spines and hairs to reduce predation (Frost, 1959). For this reason, the longer duration of the second instar of P. nigrispinus fed with caterpillars of $C$. lacinia saundersii than those fed with others prey without spines, as third or fifth instars caterpillars of A. argillacea (Lemos et al., 2003), larvae of $B$. mori (Zanuncio et al., 1990) or larvae of T. molitor (Zamperline et al., 1992; Lemos et al. 2003) was not related to the low nutritional quality of $C$. lacinia saundersii. This might be due to the biggest mechanical effect of the spines on the surface of the integument of this prey that could hinder feeding of $P$. nigrispinus nymphs. This was also shown for nymphs of $A$. grandis that did not reach the adult stage when fed on first or second instars caterpillars of $C$. lacinia saundersii (Malaguido and Panizzi, 1998). This could be explained by the fact that nymphs of more advanced instars of $P$. nigrispinus, fed with caterpillars of $C$. lacinia saundersii were less affected by spines of this prey with spines, and therefore, presented shorter duration than with other prey without spines.

The survival of $P$. nigrispinus in the fifth instar was lower than values above $80 \%$ of nymphs of this predator with third or fifth instars caterpillars of A. argillacea or larvae of $T$. molitor or $M$. domestica (Lemos et al., 2003). This lower survival and longer duration of the fifth instar $P$. nigrispinus with caterpillars of $C$. lacinia saundersii could also be attributed to the mechanical effect of the spines on the surface of the integument of this prey that could hinder the feeding of $P$. nigrispinus nymphs. However, the total of $32.5 \%$ of the nymphs of this predator reached the adult stage with caterpillars of $A$. gemmatalis. This demonstrated that differences on survival rates of $A$. grandis could be attributed to the feeding difficulty due to the presence of spines in the surface of the body of $C$. lacinia saundersii caterpillars (Malaguido and Panizzi, 1998).

The weight of newly-emerged males and females $P$. nigrispinus fed on C. lacinia saundersii (Fig. 1) was lower than that of this predator which nymphs fed on third or fifth instars A. argillacea (Lemos et al., 2003), third instar larvae of $M$. domestica (Zanuncio et al., 1990; Lemos et al., 2003), larvae of B. mori (Zanuncio et al., 1990) or larvae of T. molitor (Zamperline et al., 1992; Lemos et al., 2003). The low weight of $P$. nigrispinus females fed on $C$. lacinia saundersii confirmed the lower nutritional quality of caterpillars of this prey for this predator. 


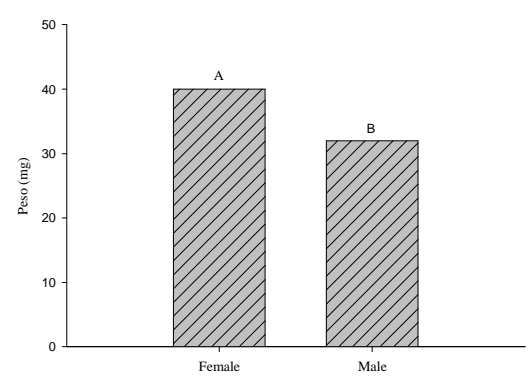

Figure 1 - Weigh (mg) of females and males of Podisus nigrispinus (Heteroptera: Pentatomidae) fed with caterpillars of Chlosyne lacinia saundersii (Lepidoptera: Nymphalidae) at $25 \pm$ $1^{\circ} \mathrm{C}, 68 \pm 10 \%$ relative humidity and 12 hours photo phase.

The sex rate of $P$. nigrispinus was 0.65 what showed higher number of females than adults. The sex ratio of Asopinae could be changed under unfavorable conditions of temperature and/or food shortage such as reported for the predominance of males of $P$. maculiventris in the laboratory during periods of prey shortage (Mukerji and Leroux, 1965). Thus, the predominance of females of $P$. nigrispinus indicated that the feeding difficulty due to the presence of spines in the integument of $C$. lacinia saundersii was not sufficient to affect the sex rate of $P$. nigrispinus.

Podisus nigrispinus developed and survived until the adult stage feeding on first or second instar caterpillars of $C$. lacinia saundersii although this prey seemed less adequate for this predator. However, the survival rate of $P$. nigrispinus during early instars could allow this predator to complement its feeding on other preys and to maintain its populations in areas with the sunflower culture.

\section{ACKNOWLEDEGEMENTS}

We thank the Brazilian agencies "Conselho Nacional de Desenvolvimento Científico e Tecnológico (CNPq), Coordenação de Aperfeiçoamento de Pessoal de Nível Superior (CAPES) and Fundação de Amparo à Pesquisa do Estado de Minas Gerais (FAPEMIG)" for funding.

\section{SUMMARY}

The nymph development and survival of Podisus nigrispinus (Dallas) (Heteroptera: Pentatomidae) fed with larvae of Chlosyne lacinia saundersii
Doubleday and Hewitson (Lepidoptera: Nymphalidae) were studied at $25 \pm 1^{\circ} \mathrm{C}$, relative humidity of $68 \pm 10 \%$ and photo phase of 12 hours. Podisus nigrispinus can develop and survive until the adult stage feeding on caterpillars of first or second instars of C. lacinia saundersii, although that prey is less appropriate for that predator. However, the survival of $P$. nigrispinus during the initial instars can allow this predator to complement its diet feeding with another prey and maintain its population in areas planted with sunflower.

\section{REFERENCES}

Arnal, E. A.; Ramos, F. (1990), Insectos relacionados con el cultivo del girassol. FONAIAP Divulga, n.33, Enero-Junio 1990. Acesso em: 23 jun 2005. Disponível em: http://www. ceniap. gov. ve/divulga/fdivul.html.

Camargo, A. J. A.; Amabile, R. F. (2001), Identificação das principais pragas do girassol na região CentroOeste. Brasília: EMBRAPA/CPAC, 4p. (EMBRAPA/CPAC, Comunicado Técnico, 50).

De Clercq, P.; DeGheele, D. (1992), Development and survival of Podisus maculiventris (Say) and Podisus sagitta (Fab.) (Heteroptera: Pentatomidae) at various constant temperatures. Can. Entomol., 124, 125-133.

Frost, S.W. (1959), Insect Life and Natural History. Dover, New York.

Gentry, G. L.; L. A. Dyer, (2002), On the conditional nature of neotropical caterpillar defenses against their natural enemies. Ecol., 83, 3108-3119.

Grazia, J. (1986), Sobre os tipos de Pentatomidae (Heteroptera) descritos por A.A. Piran e depositados no 'Museo Argentino de Ciências Naturales Bernardino Rivadàvia'. Rev. Bras. Entomol., 30, 5156. 
Lemos, W. P.; Ramalho, F. S.; Serrão, J. E.; Zanuncio, J. C. (2003), Effects of diet on development of Podisus nigrispinus (Dallas) (Heteroptera: Pentatomidae), the predator of the cotton leafworm. $J$. Appl. Entomol., 128, 12-25.

Lemos, W. P.; Ramalho, F. S.; Serrão, J. E., Zanuncio, J. C.; Bauce, E. (2006), Diet affects reproduction and number of oocytes per ovary of the predator Podisus nigrispinus (Dallas) (Heteroptera: Pentatomidae). Anim. Biol., 56, 279-287.

Malaguido, A. B.; Panizzi, A. R. (1998a), Alcaeorrhynchus grandis (Dallas): An eventual predator of Chlosyne lacinia saundersii Doubleday and Hewitson on sunflower in Northern Paraná State. An. Soc. Entomol. Brasil, 27, 671-674.

Medeiros, R. S.; Ramalho, F. S.; Zanuncio, J. C., Serrão, J. E. Effect of temperature on life table parameters of Podisus nigrispinus (Het.: Pentatomidae) fed with Alabama argillacea (Lep., Noctuidae) larvae. Journal of Applied Entomology 127(4): 209-213. 2003.

Molina-Rugama, A. J.; Zanuncio, J. C.; Zanuncio, T. V.; Oliveira M.L.R. (1998), Reproductive strategy of Podisus rostralis (Stal) (Heteroptera: Pentatomidae) females under different feeding intervals. BioControl Sci. Techn., 8, 583-588.

Molina-Rugama, J. A.; Zanuncio, J. C.; Torres, J. B.; Zanuncio, T. V. (1997), Longevidad y fecundidad de Podisus nigrispinus (Heteroptera: Pentatomidae) alimentado con larvas de Musca domestica (Diptera: Muscidae) y frijol. Rev. Biol. Trop., 45, 1125-1130.

Mukerji, M. K.; Leroux, E. J. (1965), Laboratory rearing of Quebec strain of the pentatomid predator Podisus maculiventris (Say) (Hemiptera: Pentatomidae). Phytoprotection, 46, 40-46.

Nakano, O.; Silveira Neto, S.; Zucchi, R. A. (1981), Entomologia econômica. Editora Agronômica Ceres, São Paulo

Ramalho, F. S.; Mezzomo, J. A.; Lemos, W. P.; Bandeira, C. M.; Malaquia, J. B.; Silva, J. P. S.; Leite, G. L. D.; Zanuncio, J. C. (2008), Reproductive strategy of Podisus nigrispinus females under different feeding intervals. Phytoparasitica, 36, 3037.
Torres, J. B.; Silva-Torres C. S. A.; Silva M. R.; Ferreira J. F.; (2002), Compatibilidade de inseticidas e acaricidas com o percevejo predador Podisus nigrispinus (Dallas) (Heteroptera: Pentatomidae) em algodoeiro. Neotropical Entomology, 31, 311-317.

Vendramin, J. M. and Boiça Júnior, A. L. (1994), Efeito de cultivares de girasol sobre o desenvolvimento e preferência para alimentação de Chlosyne lacinia saundersii Doubl and Hew, 1849 (Lepidoptera: Nymphalidae). An. Soc. Entomol. Brasil, 23, 81-86.

Zamperline, B.; Zanuncio, J.C.; Leite, J.E.M.; Bragança, M. A. L. (1992), Influência da alimentação de Tenebrio molitor L. 1758 (Coleoptera: Tenebrionidae) no desenvolvimento ninfal de Podisus connexivus Bergroth, $1891 \quad$ (Hemiptera: Pentatomidae). Rev. Árv., 16, 224-230.

Zanuncio, J. C.; Zanuncio, T. V.; Guedes R. N. C.; Ramalho F. S. (2000), Effect of feeding on three Eucalyptus species on the development of Brontocoris tabidus (Het.: Pentatomidae) fed with Tenebrio molitor (Col.: Tenebrionidae). Biocontrol Sci. Techn., 10, 443 - 450.

Zanuncio. J. C.; Molina-Rugama, A. J.; Serrão, J. E.; Pratissoli, D. (2001), Nymphal development and reproduction of Podisus nigrispinus (Heteroptera: Pentatomidae) fed with combinations of Tenebrio molitor (Coleoptera: Tenebrionidae) pupae and Musca domestica (Diptera: Muscidae) larvae. BioControl Sci. Techn., 11, 331-337.

Zanuncio, J. C.; Lemos, W. P.; Lacerda, M. C.; Zanuncio, T. V. (2006), Age-dependent fecundity and life-fertility tables for the predator Brontocoris tabidus (Heteroptera: Pentatomidae) in field conditions. J. Econ. Entomol., 99, 401-407.

Zanuncio, J. C.; Alves, J. B.; Leite, J. E. M.; Silva, N. R. Sartório, R. C. (1990), Desenvolvimento ninfal de Podisus connexivus Bergroth, 1891 (Hemiptera: Pentatomidae) alimentado com dois hospedeiros alternativos. Rev. Árv., 14, 164-174.

Received: April 25, 2006; Revised: August 21, 2007; Accepted: August 28, 2008. 